\author{
Ye.B. Aimagambetov ${ }^{1}$, A.I. Ignatyuk ${ }^{2}$, G.N. Amirova ${ }^{3, *}$, Ye.I. Borisova ${ }^{4}$ \\ ${ }^{1,3,4}$ Karaganda Economic University of Kazpotrebsoyuz, Karaganda, Kazakhstan \\ ${ }_{2}^{2}$ Taras Shevchenko National University of Kyiv, Kyiv, Ukraine \\ ${ }^{1}$ rector@keu.kz, ${ }^{2}$ decanat_econom@univ.kiev.ua, ${ }^{3}$ amirova.galiya@bk.ru, ${ }^{4}$ lenborisova@mail.ru \\ ${ }^{1}$ https://orcid.org/0000-0003-4590-8242, ${ }^{2}$ https://orcid.org/0000-0002-9103-6943, \\ ${ }^{3}$ https://orcid.org/0000-0001-9827-3952, ${ }^{4}$ https://orcid.org/0000-0002-1452-3481 \\ ${ }^{2}$ Scopus Author ID: 55816012800 \\ ${ }^{2}$ Researcher ID: $U-7564-2018$
}

\title{
Development of methodological foundations for the development and implementation of the state policy of reindustrialization of regional systems
}

\begin{abstract}
Object: The purpose of the study is to substantiate methodological issues of state policy and modeling of the dynamic development of regional systems as an inseparable triad "ecology-society-economy" in the conditions of various stages of reindustrialization.

Methods: methods of system analysis and economic synthesis of reindustrialization factors and assessment of their impact on the development of ecological and socio-economic systems are used, which will increase the effectiveness of state policy and management decisions in the field of scientific, technical, industrial and environmental policies.

Results: The developed methodology for assessing the state and dynamics of the development of ecological and socio-economic systems is a tool for further, more in-depth analysis of the development problems of the countries that are part of the EAEU zone, in solving which it is impossible to do without the use of methods of state regulation of the economy. It is established that socio-economic policy and the organizational, economic, and managerial mechanisms by which it is implemented have a significant impact on development. In this regard, it is important not only to determine the degree of efficiency of the use of available resources, but also to what extent and how to make up for their lack. The presence or absence of effective policies is reflected in the reduction or growth of barriers to development.

Conclusions: Recommendations on the choice of reindustrialization options are as follows:

- systematic consideration of three interrelated elements: realization of industrial potential, effective use of labor resources, ensuring normal working conditions and effective employment of the population; advanced development of infrastructure;

- consideration of environmental effects directly related to the process of re-industrialization;

- a retrospective study of the industrial development of the territory is the most important source of information for the development of directions for the allocation of productive forces;

- decision-making is based on taking into account social, economic, natural and technological criteria indicators, which provide for compliance with the principle of coordinating the interests of the subjects of reindustrialization, taking into account social priorities.
\end{abstract}

Keywords: state policy, reindustrialization, methodological approaches, regional systems, ecological-socioeconomic systems.

\section{Introduction}

The current stage of socio-economic transformations in the countries of the Eurasian Economic Union (EAEU) zone is characterized by an active search for development prospects. The economic crisis has made significant adjustments both to the situation in the economies of different countries and to the state of world markets, requiring a reassessment of the parameters and forecasts of socio-economic development, changing approaches to the formation of development programs for various sectors of the national economy. But the most important conclusion, which follows from the analysis of the prerequisites and consequences of the crisis, is that the world is on the verge of large-scale technical, cultural and social changes that require the restructuring of the basic foundations of socio-economic systems. In this regard, the governments of the EAEU countries are forced not just to carry out reindustrialization, but practically to engage in the industrialization of the economy from scratch, since the industry, due to known political reasons, was completely destroyed or technologically obsolete (Shelomentsev, at al. 2017). In this regard, within the framework of this study, rein-

\footnotetext{
${ }^{*}$ Corresponding author.

E-mail address: amirova.galiya@bk.ru
} 
dustrialization is understood as the design and deployment of internal industrial and technological chains that create use values for both industrial and consumer purposes.

The processes of state regulation of the socio-economic consequences of reindustrialization should be dynamic and flexible. In all countries with established market economies, the concepts, goals, objectives, priorities and mechanisms of industrial development have changed with economic development (Taubayev, Amirova, Borisova, 2019). Reindustrialization is impossible without strengthening the role of the state on the basis of a comprehensive socio-economic policy in relation to specific industrial complexes and industries.

Currently, research in this area is more focused on the general issues of reindustrialization, including imperatives, opportunities, challenges, and the impact of global factors and risks on these processes. The issues of public administration are practically not touched upon. The developed foreign concepts are poorly suited to the conditions in the EAEU countries, so they can only be considered as a basis for studying theoretical and practical experience that can be adapted for the countries within the EAEU. In addition, the issues of modeling the dynamic development of regional systems as an inseparable triad "ecology - society - economy" in the conditions of various stages of reindustrialization of the EAEU countries have not yet received proper theoretical and methodological study.

\section{Literature Review}

The founders of bringing to the fore the concept of reindustrialization as an innovative approach to the development of industrial systems can be noted (Stevenson, 1981) and (Roy Rothwell, 1985), who justified the conditions and prerequisites for this process in the world economy. Also, in this series, we can note the role of specialized studies of international scientific organizations (National Research Council, 1981), which have developed methodological recommendations for understanding terminology related to the development of reindustrialization processes. The study by (Roy Rothwell, 1985) examines the close relationship between reindustrialization and the development of science and technology, and determines the priority of industry development from the point of view of innovation and transition to new technological processes based on the developments of domestic science. In the future, the development of the theoretical aspects of the problem of reindustrialization became controversial within the framework of clarifying the terminology of the process and the various shades of the name of reindustrialization, which was reflected in the study of (Raggi, 2013).

At the present stage, instead of theoretical questions, research in the field of reindustrialization of national economies has come to the fore in the direction of determining readiness, priorities, resource provision and assessing the impact on national competitiveness. The readiness of post-socialist countries for reindustrialization in the context of increasing globalization is considered in the study by (Levin, 2010) which presents data not only on possible directions of reindustrialization, but also on the misconceptions inherent in stimulating this process in state policy. In addition, we can note the research of (Shih, 2013) and (Panza, 2014), which consider the key features of the reindustrialization of the United States and the Middle East, and in comparing the data, the study shows a clear dependence of the reindustrialization process on the level of development of countries. If for developed countries reindustrialization is an opportunity to move to a new technological level, then for developing countries an incorrectly developed and implemented state policy of reindustrialization can lead to deindustrialization, and to a decrease in the technological level.

It should be noted that now all the countries of the Eurasian Economic Union (EAEU), including Russia and Kazakhstan, have identified reindustrialization on a new technological basis as the main priority for the development of industry. Therefore, we study not only the features of the reindustrialization process, but also its impact on the main economic and social processes, so at this stage there are a lot of studies of this nature. Among them, we can note the study of (Shelomentsev, at al. 2017), which addresses the issues of the regional level of reindustrialization in the EAEU countries, from the perspective of a detailed study of the issues of modeling the dynamic development of regional systems as an inseparable triad "ecology-society-economy" in the conditions of various stages of reindustrialization of the EAEU countries. This study also raises questions about the further continuation of the study of reindustrialization processes in the EAEU countries, since the process is long-term and requires a well-developed state and supranational policy. In the study of (Nevskaya, et al. 2018) the transformation of the system of indicators of the state economic policy aimed at stimulating the development of economic potential in order to increase the competitiveness of the national economy with a priority on the reindustrialization of the Russian economy is considered. Among the Kazakh authors, I would like to mention the study by (Aimagambetov, et al. 2016), in which the authors consider the possibilities of reindustrialization of the national economy from the point of view of ensuring its competitiveness. Assessing the factors of ensuring competitiveness, the authors note the role of national industry and 
the business environment (Davletbayeva, Taubayev, Kuttybai, 2018) as the main actors in the processes of reindustrialization.

\section{Method}

A special feature of the proposed approach is the consideration of the national economies of the EAEU countries as regional ecological and socio-economic systems. Therefore, first of all, we will define the content of the concept of "ecological-socio-economic system" in relation to the national economies of the EAEU countries.

A systematic approach is now a common requirement when analyzing any problem that needs a scientific solution. At the same time, the general concept hides a diverse set of ideas about consistency. In our opinion, there are three main understandings of the term "system", which complement each other and are associated with successive stages of scientific research and construction in the economy.

The methodology for assessing the state and dynamics of the development of ecological and socioeconomic systems is a tool for further, more in-depth analysis of the development problems of the countries that are part of the EAEU zone, in solving which it is impossible to do without the use of methods of state regulation of the economy (Taubayev, Kamenova, Borisova, Saifullina, 2019).

Methodological provisions for assessing the impact of reindustrialization processes on the socioeconomic development of ecological and socio-economic systems take into account:

- transition of the economy to an innovative development path;

- linking the strategic goals and priorities of the national economies and the EAEU as a whole;

- efficient use of all types of resources.

The results of the assessment of the impact of reindustrialization processes and the development of ecological, socio-economic systems should be the basis for decisions taken by the authorities of the EAEU countries in the field of scientific, technical, industrial and environmental policies. Decisions should be aimed at ensuring the sustainable socio-economic development of countries based on the rational use of natural resources.

At the same time, a special role is played by factors related to nature management and environmental protection, which, through economic mechanisms, affect the socio-economic development of the EAEU member states as a whole. This is reflected in the main parameters of the vital activity of national economies: economic growth, income of the population, law and order and public safety, public health, education, culture, physical culture and sports, accessibility and quality of housing, state and municipal administration.

\section{Results}

The traditional view of the industrial system can be formulated in the following terms:

1. The system is closed and has a certain stability of goals and operating conditions.

2. Orientation of the system to mass production of goods and services.

3. The main factor of efficiency is the growth of profit generated in the conditions of rational use of all resources.

4. The organization and management system is based on the functional division of labor, norms and rules that ensure the effective use of resources.

The increasing complexity of global political and socio-economic processes is reflected in the active development of institutional theories in order to find solutions to systemic problems. According to the representatives of the socio-institutional direction, the new society is characterized by a significant increase in the role of man in the economy and the formation of a new type of production, economic and socio-cultural relations.

The content of modern views on the development of industrial systems can be briefly described as follows:

1. The system is considered in the unity of the influence of the internal and external environment.

2. Focus on product quality, on meeting the needs of individualized consumers.

3. The main source of profit is the staff with creative potential, as well as the conditions for its implementation.

4. The management system is focused on the growth of organizational, labor culture and innovations.

There are several approaches to building a system for measuring the socio-economic state, level and pace of development of the national economy:

- comparison by a single indicator selected as the main indicator;

- comparison of several indicators identified as priority for the socio-economic development of the region; 
- building a system of consolidated socio-economic indicators;

- construction of rating points.

The first two approaches are used in mathematical modeling of both the regional socio-economic system as a whole and its structural elements. In the third approach, the principle of selecting and matching indicators is important. To achieve the optimality of the system, methods for constructing indicators are developed. For each indicator, each region gets its own rank (place) and score in points. Then the standard score for the indicator as a whole is calculated. You can evaluate a region by a coefficient that is equal to the ratio of the region's own score to the standard score for a specific indicator. All coefficients will be in the range from 0 to 1 , the higher the value, the better the position of the region according to this criterion.

The territorial proportions of the development of productive forces reflect the participation of each region in the formation of the economic potential of the country at various stages of its development. This includes the production and non-production sectors of the economy, which are based on taking into account numerous, often multidirectional prerequisites and restrictions for the development of territories. The construction of typologies (or typological groupings) of regions is important both for the systematic description and diagnosis of the socio-economic situation of the regions, and for the implementation of the tasks of the state regional socio-economic policy. A prerequisite for the development of mechanisms and instruments of regional economic policy should be taking into account the economic, social, natural, geopolitical and other significant features of the regions.

In regional studies, methods of typological groupings of regions are widely used. At the same time, preference is given to the methods of complex groupings, when the division of a set of regions into groups (types) is carried out according to two or more characteristics taken in combination (combinations). A group of indicators with a certain thematic focus can be considered as a certain potential of the region in a particular area of economic development.

The economic advantages of individual countries include the availability of skilled labor, developed agriculture, the capacity and degree of diversification of industrial potential, the presence of a monopoly on scarce or export resources, the presence of unique industries and monopolistic enterprises, and a favorable economic and geographical location (border, coastal and transit regions) (Bliakhman, 2014).

With the transition to market - based principles of organizing social production, the competitive struggle of countries for resources to maintain and increase their socio-economic potential has become clear. In this competition, the comparative conditions of investment and functioning of capital and labor acquire a systematic character. The main goal and task of various countries is to assert themselves in the market space, to create an economic and managerial infrastructure that can ensure their success in the competition for investment, financial, and labor resources. From the point of view of the development of specific industries, the inflow of capital to a particular region is practically no longer dependent on centralized solutions, but is determined by the competitive capabilities of the region and the prospects for their expansion. Entrepreneurial capital flows to those countries and regions, as well as areas of activity where it is possible to place competitive production and organize profitable business.

Stable development of ecological-socio-economic system, and, consequently, all of the structural elements of this system is in direct proportion to the degree of possession of the corresponding potential for development, which determines the attractiveness of the country for new and reconstruction of existing facilities.

Based on the above, the methodological basis for assessing the impact of regional factors on the state and development of national economies in this study is the principles of the allocation of productive forces:

1. Territorial division of labor: improving the competitiveness of the national economy as a result of using the absolute and relative advantages of the division of labor between countries within their territories, using the economic benefits of the interregional and international division of labor.

Expected result: formation of effective market specialization, optimal employment structure, economic relations with other EAEU countries, taking into account economic, natural-resource and historical conditions and features of development, restoration and development of integration ties, conclusion of intergovernmental agreements on mutual supply of products, agreements on joint work on commissioning of production facilities, carried out on a mutually beneficial basis.

Risks: the weakness of internal integration, the lack of a common economic space, territorial isolation.

2. Rational and efficient placement of production: bringing production closer to the sources of raw materials, fuel, energy and consumption areas in order to reduce production costs; improving the environmental situation 
Expected result: reduction of transport, energy, material and labor costs, increase of economic efficiency of production;

Risks: unfavorable natural and climatic conditions; high cost of living of the population and, as a result, high cost of labor, or low standard of living; high production costs.

3. Integrated socio-economic development of national economies: development of sectoral and intersectoral clusters.

Expected result: reduced environmental and production costs, increased employment efficiency as a result of the agglomeration effect.

Risks: territorial isolation, non-integrated nature of the economy, excessive orientation to the external market, the desire of foreign partners to direct the development of economic relations along the way of exporting raw materials and products of initial processing from the country.

4. Smoothing the asymmetry of the economic and social development of the EAEU countries: accelerating the pace of development of not only prosperous, but also backward territories.

Expected result: increased competitiveness and investment attractiveness on the basis of a well-thoughtout development policy, reduction of hotbeds of social tension in the most backward economies that can destabilize the situation as a whole.

Risks: a significant gap between countries in terms of socio-economic development, the inability to overcome country differentiation over a long period of time, and the lack of financial resources.

Depending on the scope and nature of the manifestation of these factors in a particular socio-economic environment, the degree of their influence can be quite significant and manifest itself in both positive and negative aspects, becoming in the latter case barriers to development. Table 1 highlights the most important ones, which primarily determine the effectiveness of the socio-economic policy implemented in a particular country.

Table 1. Types of barriers to regional development and areas of their manifestation

\begin{tabular}{|c|c|}
\hline Types of barriers & The focus of barriers \\
\hline Economic & $\begin{array}{l}\text { The ability of the regional economy to effectively use available resources to produce goods } \\
\text { and services in accordance with the requirements of the domestic and foreign markets. }\end{array}$ \\
\hline Investment projects & Objective resource opportunities for the implementation of investment development goals \\
\hline $\begin{array}{l}\text { Economic and geo- } \\
\text { graphical features }\end{array}$ & $\begin{array}{l}\text { The state of economic development, indicating the degree of economic development of the } \\
\text { territory, determined by the influence of natural and geographical features of the develop- } \\
\text { ment of the national economy }\end{array}$ \\
\hline Financial services & $\begin{array}{l}\text { The financial capacity of the national economy to meet the expenditure obligations and } \\
\text { powers assigned to it by the legislation to ensure comprehensive socio-economic develop- } \\
\text { ment, without resorting to external financial assistance. }\end{array}$ \\
\hline $\begin{array}{l}\text { Infrastructure pro- } \\
\text { jects }\end{array}$ & $\begin{array}{l}\text { The level of infrastructure development of the territory, as the most important condition for } \\
\text { attracting and concentrating production and population on the territory of the country, the } \\
\text { development of trade, financial and information services, and innovation. }\end{array}$ \\
\hline Social networks & $\begin{array}{l}\text { The state and conditions of social development of the territory that determine the standard of } \\
\text { living of the population of the country, resulting from the consumption of economic and } \\
\text { social benefits created by the market and public sectors of the national economy }\end{array}$ \\
\hline Demographics & $\begin{array}{l}\text { The population, its reproductive capacity, as a result of prolonged exposure on the dynamics } \\
\text { and age structure of the population of the mode of generation, due to demographic and mi- } \\
\text { gratory behaviour of the population. }\end{array}$ \\
\hline Labor relations & $\begin{array}{l}\text { The state of employment, which characterizes its quality level that meets the standards of the } \\
\text { International Labour Organization (ILO). }\end{array}$ \\
\hline Institutional & $\begin{array}{l}\text { The qualitative level of the management functions performed by the national authorities to } \\
\text { create conditions for the growth of the country's competitiveness, determined by the effec- } \\
\text { tiveness of the state socio-economic policy implemented in the territory. }\end{array}$ \\
\hline Ecological & $\begin{array}{l}\text { The level of anthropogenic load on the environment, which determines the degree of its suit- } \\
\text { ability for the life support of the population and the conduct of economic activity. }\end{array}$ \\
\hline $\begin{array}{l}\text { Production and tech- } \\
\text { nological }\end{array}$ & $\begin{array}{l}\text { The level of capacity of the real sector to use available resources to solve socio-economic } \\
\text { problems of the development of the national economy. }\end{array}$ \\
\hline
\end{tabular}

Based on the above basic principles of the development and distribution of productive forces, the main factors of influence on the development of ecological, socio-economic systems are identified and grouped into 11 blocks (dominants): 
The first block (economic) factors describes the conditions that define the place and role of the country in the international division of labor, the degree of export-oriented economic complex of the territory, giving an idea about the type, level of development and the structure of the production complex.

The second block (investment) forms the investment potential and activity of the country and its regions, attracting investment in the development of the national economy.

The third set of factors characterizes the level of economic development of the territory and indicates the degree of its economic and infrastructural development associated with the natural and geographical conditions of development.

The fourth set of factors characterizes the financial condition of the territory, due to the budget's fullness and the ability of the government to fulfill its obligations to society.

The fifth (infrastructure) block makes it possible to determine the level of development of industrial, transport, and social infrastructure, which forms the basis for the prospects for the development of the national economy and its investment attractiveness for both domestic and foreign investors.

The sixth (social) block characterizes the level of social development of the territory and is associated with the formation of the level and quality of life of the population of a given country, its social well-being, which determines the potential of migration outflow from the territory of the country or, conversely, its inflow.

The seventh (demographic) block of factors determines the presence and level of development of the demographic potential of the country, the conditions of reproduction of the population, its gender and age composition, migration activity, which ultimately forms the country's labor resources.

The eighth (labor) block of factors is closely related to the previous two, which form the basis for the formation and development of the country's labor potential.

The institutional block characterizes the share of the state's presence in the formation of economic activity in the country and its regions and takes into account the impact of the socio-economic development strategy implemented in the country, including state programs at the federal and regional levels. This set of factors takes into account the role of the state in creating an environment for improving the country's competitiveness and ensuring its economic and national security.

Tenth unit factors determines the level of ecological well-being of the country, the state of the environment, which, due to natural and climatic characteristics of the territory or as a result of high environmental load of sectors on the environment determine the restrictions to further increase production capacity at the same technological basis.

The last block (production and technological) factors characterizes the level of technological development of the national economy and is directly related to the previous one.

When all groups of factors interact, an ecological and socio-economic environment is formed that promotes or, conversely, hinders the development of the territory. Each of the circles of the diagram shown in Figure 1, and the whole of it, illustrates the essential components of the influence on the nature and level of development of the system. At the same time, each of the components determines the corresponding group of factors in the system of barrier influence. The effect of one of the components can largely be determined by the state of the others.

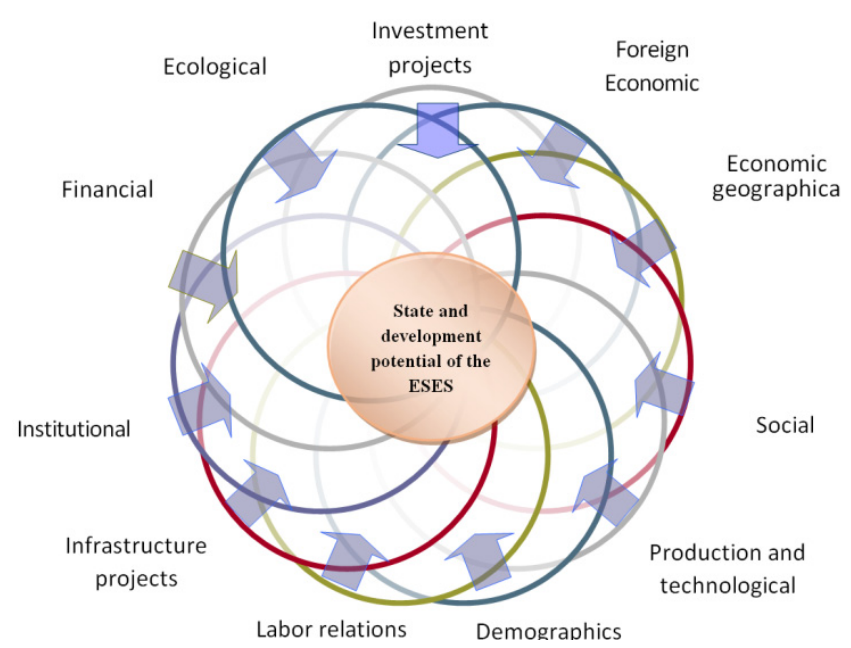

Figure 1. Factors determining the state and development potential of ecological and socio-economic systems (ESES) Note - Compiled by the author 
For example, the presence of production factors will not automatically lead to the development of industrial enterprises, if the level of infrastructure or socio-economic development of the territory does not contribute to the formation of a favorable investment climate.

Significant differentiation in the socio-economic state and dynamics of the development of ecological and socio-economic systems is largely due to resource availability, geographical location, climatic conditions and a number of other objective factors. At the same time, along with this, socio-economic policy and the organizational, economic, and managerial mechanisms by which it is implemented have a significant impact on development. In this regard, it is important not only to determine the degree of efficiency of the use of available resources, but also to what extent and how their lack is compensated. The presence or absence of effective policies is reflected in the reduction or growth of barriers to development.

Based on the above methodological approach, the ESES are divided according to their belonging to a particular group:

1) with a low level of barrier risks in development;

2) the average level of barrier risks;

3) with high barrier risks.

If the gap between the minimum and maximum values of the indicator is too large, and the step interval increases significantly, the search for the minimum and maximum values is reduced to finding the most common minimum or maximum values of this indicator in the selected range, and then determining the weighted average value.

Conducting both a general analysis and an analysis of individual blocks of indicators will help identify weak links in socio-economic development and develop more effective measures to eliminate or reduce the impact of development barriers that have a negative impact on the ESEC, as well as strengthen the effect of positive factors.

\section{Discussion}

When assessing the impact of reindustrialization processes on the development of ecological and socioeconomic systems, we proceed from the fact that in the modern economic theory and practice of regional research, there is a variety of methodological materials, but there are no specific methods of diagnosis and forecasting. This should be solved the issue of obtaining reliable information about the features of the socioeconomic situation in a particular region, comprehensive assessment and integrated analysis of statistical, sociological and other information about the socio-economic situation in the territory, the development of socio-economic development of the territory and preparation of recommendations aimed at overcoming the negative and support the positive trends of socio-economic development, bring these recommendations to the relevant authorities and management.

\section{Conclusion}

Thus, the features of the author's approach to the choice of reindustrialization options are as follows:

- systematic consideration of three interrelated elements: realization of industrial potential, effective use of labor resources, provision of normal working conditions and effective employment of the population; advanced development of infrastructure;

- consideration of environmental effects directly related to the process of re-industrialization;

- a retrospective study of the industrial development of the territory is the most important source of information for the development of directions for the allocation of productive forces;

- decision-making is based on taking into account social, economic, natural and technological criteria indicators, which provide for compliance with the principle of coordinating the interests of the subjects of reindustrialization, taking into account social priorities.

The development of effective economic tools for solving the strategic tasks of reindustrialization of the national economy is not limited to justifying the scale of state support for the industrial sector.

At the same time, the effect of improving economic instruments is to:

- ensuring the global competitiveness of a particular country and its regions;

- stimulating the process of consolidating the resources of the national economy for accelerated growth and changing its structure;

- development of human capital, improvement of spatial and qualification mobility of the population;

- improving the environmental situation to balance economic development;

- improving the quality of public goods management, including natural resources. 
The degree of achievement of the set goals determines the sustainability and dynamism of the development of the national economy, as well as the formation of potential for its future development.

The development of public policy implementation tools means:

- justification of clear criteria for assessing the effectiveness of reindustrialization in the areas of nature management and environmental protection, as well as their correlation with strategic goals and tactical objectives of socio-economic development in general;

- socio-economic forecast of the consequences of the transformation of existing and the introduction of new economic mechanisms and tools;

- the sequence of decisions and actions to introduce innovations in the mechanisms and tools of public administration.

The recommendations, based on the relevant conclusions and conclusions, should be:

- focused on specific activities and addressed to specific public administration bodies;

- practical, that is, feasible in the medium term and taking into account legal and other restrictions;

- cost-effective, that is, the results, and the activities associated with them, should not exceed the costs;

- focused on specific socio-economic outcomes.

\section{References}

Aimagambetov, E., Stefanov, D. \& Kuttybaeva, N. (2016). Assessing the level of competitiveness of the Republic of Kazakhstan on the basis of world rankings analysis. International Journal of Economic Perspectives. 10. 101-112.

Bliakhman, L.S. (2014). Regionalnye i makroregionalnye osnovy novoi industrializatsii [Regional and macro-regional foundations of the new industrialization]. Problemy sovremennoi ekonomiki - Problems of the modern economy. 1(49), 7-18 [in Russian].

Davletbayeva, N., Taubayev, A. \& Kuttybai, M. (2018). System problems of entrepreneurship development in Kazakhstan regions in conditions of globalization. IDIMT 2018: Strategic Modeling in Management, Economy and Society. 26th Interdisciplinary Information Management Talks. pp. 113-119. Retrieved from https://idimt.org/wpcontent/uploads/proceedings/IDIMT_proceedings_2018.pdf

Levin, S.M. (2010). Alternatives to institutional development of frontier and post-socialist countries: mythologems of "postindustrialism" and "globalism" and the real trends, Institutional Research Journal, Vol. 2, Issue 1, pp. 6-16

National Research Council. (1981). Reindustrialization or New Industrialization: Minutes of a Symposium. Washington, DC: The National Academies Press. https://doi.org/10.17226/19675.

Nevskaya, N.A., Garnov, A.P., Brykin, A.V. \& Malakhova, E.V. (2018). National Competitiveness as the Object of Indicative Planning in the Context of Re-industrialization. European Research Studies Journal, Volume XXI, Special Issue 1, 148-155, DOI: $10.35808 / \mathrm{ersj} / 1167$

Panza, L. (2014). De-industrialization and re-industrialization in the Middle East: reflections on the cotton industry in Egypt and in the Izmir region. The Economic History Review, 67(1), 146. doi: 10.1111/1468-0289.12019

Raggi, P. (2013). Industrialisation, désindustrialisation, ré-industrialisation en Europe: Le cas de la sidérurgie lorraine (1966-2006). Rives méditerranéennes, no 46,(3), 11-28. doi:10.4000/rives.4478.

Roy Rothwell, (1985). Reindustrialization and technology: Towards a national policy framework. Science and Public Policy, Volume 12, Issue 3, June 1985, Pages 113-130, https://doi.org/10.1093/spp/12.3.113

Shelomentsev, A.G., Taubayev, A.A., Berg, D.B., \& Ulybyshev, D.N. at al. (2017). Modelirovanie stsenariev dinamichnogo razvitiia regionalnykh ekologo-sotsio-ekonomicheskikh sistem $\mathrm{v}$ usloviiakh reindustrializatsii stran Evraziiskogo ekonomicheskogo soiuza [Modeling of scenarios of dynamic development of regional ecological and socio-economic systems in the context of reindustrialization of the countries of the Eurasian Economic Union]. Karaganda: TOO «PEGASO», 250 p. [in Russian].

Shih, Willy C. (2013). "The Re-Industrialization of the United States?" Wirtschaftspolitische Blätter 60, N. 2. Pp. $297-$ 312.

Stevenson, A.E. (1981). Reindustrialization: politics and economics. United States: N.p., Web. doi:10.1080/05775132.1981.11470659.

Taubayev, A.A., Amirova, G.N. \& Borisova, E.I. (2019). The main trends in the development of science-intensive economy in the conditions of reindustrialization of the countries of the Eurasian Economic Union. Economic series of the Bulletin of L.N. Gumilyov, 3, 55-63

Taubayev, A.A., Kamenova, A.B., Borisova, E.I. \& Saifullina, Yu.M. (2019). Formirovanie v Kazakhstane institutsionalnoi sredy razvitiia vysokotekhnologichnogo sektora i innovatsionnogo predprinimatelstva [Formation in Kazakhstan institutional environment for the development of high-tech sector and innovative entrepreneurship]. Korporativnoe upravlenie i innovatsionnoe razvitie ekonomiki Severa - Corporate Governance and Innovative Economic Development of the North, 1, 104-111. DOI: 10.34130/2070-4992-2019-1-104-111 [in Russian]. 


\section{Е.Б. Аймагамбетов, А.И. Игнатюк, Г.Н. Амирова, Е.И. Борисова}

\section{Өңірлік жүйелерді қайта индустрияландырудың мемлекеттік саясатын әзірлеу мен іске асырудың әдістемелік негіздерін дамыту}

\section{Андатпа}

Maқ̧cambl: Зерттеудің мақсаты мемлекеттік саясаттың әдістемелік мәселелерін негіздеу және қайта индустрияландырудың әр түрлі кезеңдері жағдайында «экология - социум - экономика» ажырамас үштігі ретінде өңірлік жүйелердің серпінді дамуын модельдеу болып табылады.

Әдістері: Қайта индустрияландыру факторларын жүйелі талдау және экономикалық синтездеу және олардың экологиялық-әлеуметтік-экономикалық жүйелердің дамуына әсерін бағалау әдістері пайдаланылды, бұл ғылыми-техникалық, өнеркәсіптік және табиғатты қорғау саясаты саласындағы мемлекеттік саясат пен басқарушылық шешімдердің тиімділігін арттыруға мүмкіндік береді.

Нәтижесі: Экологиялық-әлеуметтік-экономикалық жүйелердің жай-күйі мен даму серпінін бағалаудың әзірленген әдістемесі ЕАЭО аймағына кіретін елдердің даму проблемаларын одан әрі, неғұрлым терең талдаудың құралы болып табылады, оларды шешуде экономиканы мемлекеттік реттеу әдістерін пайдаланбай істеу мүмкін емес. Дамуға әлеуметтік-экономикалық саясат және оны жүзеге асыратын ұйымдастырушылық, экономикалық, басқару тетіктері айтарлықтай әсер ететіні анықталды. Осыған байланысты қолда бар ресурстарды пайдалану тиімділігінің дәрежесін анықтау ғана емес, сонымен қатар олардың жетіспеушілігі қаншалықты және қалай толықтырылатыны да маңызды. Тиімді саясаттың болуы немесе керісінше болмауы даму кедергілерінің төмендеуінде немесе өсуінде көрініс табады.

Қорытынды: Қайта индустрияландыру нұсқаларын таңдау бойынша ұсыныстар:

- өзара байланысты үш элементті жүйелі қарау: өнеркәсіптік әлеуетті іске асыру, еңбек ресурстарын тиімді пайдалану, қалыпты еңбек жағдайларын және халықты тиімді жұмыспен қамтуды қамтамасыз ету; инфрақұрылымды озыңқы дамыту;

- қайта индустрияландыру үдерістерімен тікелей байланысты экологиялық зардаптарды есепке алу;

- аумақтың индустриялық дамуын ретроспективті зерделеу өндіргіш күштерді орналастыру бағыттарын әзірлеу үшін маңызды ақпарат көзі болып табылады;

- шешімдер қабылдау әлеуметтік басымдықтарды ескере отырып, қайта индустрияландыру субъектілерінің мүдделерін келісу қағидатын сақтауды көздейтін әлеуметтік, экономикалық, табиғи және технологиялық өлшем көрсеткіштерін есепке алуға негізделеді.

Кілm сөздер: мемлекеттік саясат, қайта индустрияландыру, әдістемелік тәсілдер, өңірлік жүйелер, экологиялық-әлеуметтік-экономикалық жүйелер.

\section{Е.Б. Аймагамбетов, А.И. Игнатюк, Г.Н. Амирова, Е.И. Борисова}

\section{Развитие методических основ разработки и реализации государственной политики реиндустриализации региональных систем}

\section{Аннотация}

Цель: Цель исследования заключается в обосновании методических вопросов государственной политики и моделирования динамичного развития региональных систем как неразрывной триады «экология - социум экономика» в условиях различных этапов реиндустриализации.

Memodbl: Использованы методы системного анализа и экономического синтеза факторов реиндустриализации и оценки их влияния на развитие эколого-социо-экономических систем, что позволит повысить эффективность государственной политики и управленческих решений в сфере научно-технической, промышленной и природоохранной политики.

Pезультаты: Разработанная методика оценки состояния и динамики развития эколого-социоэкономических систем является инструментом для дальнейшего, более глубокого анализа проблем развития стран, входящих в зону ЕАЭС, в решении которых невозможно обойтись без использования методов государственного регулирования экономики. Установлено, что существенное влияние на развитие оказывают социальноэкономическая политика и те организационные, экономические, управленческие механизмы, которыми она осуществляется. В связи с этим важное значение приобретает не только определение степени эффективности использования имеющихся ресурсов, но и то, насколько и каким образом восполняется их недостаток. Наличие или, наоборот, отсутствие эффективной политики отражается в снижении или росте барьеров развития.

Bblвoдbl: Рекомендации по выбору вариантов реиндустриализации заключаются в следующем:

- системное рассмотрение трех взаимосвязанных элементов: реализации промышленного потенциала, эффективного использования трудовых ресурсов, обеспечения нормальных условий труда и эффективной занятости населения; опережающее развитие инфраструктуры;

- учет экологических последствий, непосредственно связанных с процессами реиндустриализации;

- ретроспективное изучение индустриального развития территории является важнейшим источником информации для разработки направлений размещения производительных сил; 
- принятие решений базируется на учете социальных, экономических, природных и технологических критериальных показателей, предусматривающих соблюдение принципа согласования интересов субъектов реиндустриализации с учетом социальных приоритетов.

Ключевые слова: государственная политика, реиндустриализация, методические подходы, региональные системы, эколого-социо-экономические системы.

\section{References}

Aimagambetov, E., Stefanov, D. \& Kuttybaeva, N. (2016). Assessing the level of competitiveness of the Republic of Kazakhstan on the basis of world rankings analysis. International Journal of Economic Perspectives. 10. 101-112.

Davletbayeva, N., Taubayev, A. \& Kuttybai, M. (2018). System problems of entrepreneurship development in Kazakhstan regions in conditions of globalization. IDIMT 2018: Strategic Modeling in Management, Economy and Society. 26th Interdisciplinary Information Management Talks. pp. 113-119. Retrieved from https://idimt.org/wpcontent/uploads/proceedings/IDIMT_proceedings_2018.pdf

Levin, S.M. (2010). Alternatives to institutional development of frontier and post-socialist countries: mythologems of «postindustrialism» and «globalism» and the real trends, Institutional Research Journal, Vol. 2, Issue 1, pp. 6-16

National Research Council. (1981). Reindustrialization or New Industrialization: Minutes of a Symposium. Washington, DC: The National Academies Press. https://doi.org/10.17226/19675.

Nevskaya, N.A., Garnov, A.P., Brykin, A.V. \& Malakhova, E.V. (2018). National Competitiveness as the Object of Indicative Planning in the Context of Re-industrialization. European Research Studies Journal, Volume XXI, Special Issue 1, 148-155, DOI: 10.35808/ersj/1167

Panza, L. (2014). De-industrialization and re-industrialization in the Middle East: reflections on the cotton industry in Egypt and in the Izmir region. The Economic History Review, 67(1), 146. doi: 10.1111/1468-0289.12019

Raggi, P. (2013). Industrialisation, désindustrialisation, ré-industrialisation en Europe: Le cas de la sidérurgie lorraine (1966-2006). Rives méditerranéennes, no 46,(3), 11-28. doi:10.4000/rives.4478.

Roy Rothwell, (1985). Reindustrialization and technology: Towards a national policy framework. Science and Public Policy, Volume 12, Issue 3, June 1985, Pages 113-130, https://doi.org/10.1093/spp/12.3.113

Shih, Willy C. (2013). «The Re-Industrialization of the United States?» Wirtschaftspolitische Blätter 60, N. 2. Pp. 297312.

Stevenson, A.E. (1981). Reindustrialization: politics and economics. United States: N.p., Web. doi:10.1080/05775132.1981.11470659.

Taubayev A.A., Amirova G.N., Borisova E.I. The main trends in the development of science-intensive economy in the conditions of reindustrialization of the countries of the Eurasian Economic Union. -//Economic series of the Bulletin of L.N. Gumilyov. — № 3. - 2019. - p. 55-63

Бляхман Л.С. Региональные и макрорегиональные основы новой индустриализации / Л.С. Бляхман // Проблемы современной экономики. - 2014. - № 1 (49). - С. 7-18.

Таубаев А.А. Формирование в Казахстане институциональной среды развития высокотехнологичного сектора и инновационного предпринимательства / А.А. Таубаев, А.Б. Каменова, Е.И. Борисова, Ю.М. Сайфуллина // Корпоративное управление и инновационное развитие экономики Севера. — 2019. — № 1. — С. $104-111$. DOI: $10.34130 / 2070-4992-2019-1-104-111$

Шеломенцев А.Г. Моделирование сценариев динамичного развития региональных эколого-социоэкономических систем в условиях реиндустриализации стран Евразийского экономического союза: моногр. [Текст] / А.Г. Шеломенцев, А.А. Таубаев, Д.Б. Берг, Д.Н. Улыбышев и др. - Караганда: Изд. TOO «PEGASO», 2017. - $250 \mathrm{c}$. 